\title{
Protein Map Standardization of Human Saliva Using Two Dimensional Gel Electrophoresis (2-DE)
}

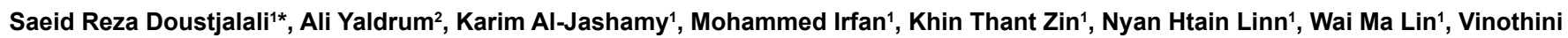
Appalanaidu', Samiah Yasmin Abdul Kadir ${ }^{1}$, Jeyaseelan Nadankutty ${ }^{1}$, Rohaini Mohamad ${ }^{1}$, Wong A-Chin ${ }^{1}$, Htet Htet ${ }^{1}$, Ahmad Yusuf', Rebecca SY Wong ${ }^{1}$, Vinoth Kumarasamy ${ }^{1}$, Christinal PW Teh ${ }^{1}$, Nazrila SF Suhaimi', Hafiza Arzuman ${ }^{1}$, Aida Nur Ashikin Abdul Rahman ${ }^{3}$, Marzalina Mansor ${ }^{4}$, Shamala Devi Sekaran ${ }^{5}$ and Negar Shafiei Sabet ${ }^{1,5 *}$

${ }^{1}$ Faculty of Medicine, SEGi University, Kota Damansara, Selangor, Malaysia

${ }^{2}$ Faculty of Dentistry, SEGi University, Kota Damansara, Selangor, Malaysia

${ }^{3}$ Faculty of Dentistry, Universiti Teknologi Mara (UiTM), Shah Alam, Selangor, Malaysia,

${ }^{4}$ Forest Research Institute Malaysia (FRIM), Selangor, Malaysia

${ }^{5}$ Tropical Infectious Diseases Research and Education Center (TIDREC), Department of Medical Microbiology, Faculty of Medicine, University of Malaya, Kuala Lumpur, Malaysia

\begin{abstract}
Over the past decade, the use of saliva as an auxiliary diagnostic tool for biomarker detection has gained considerable acceptance as a non-invasive, inexpensive alternative to conventional serum method. In proteomics, the most promising technique which can be used for detecting salivary biomarker with sufficient resolving power is two-dimensional gel electrophoresis (2-DE) that provides a unique platform for the simultaneous separation of proteins in a complex mixture. However, as a fact most of the new scientists in developing countries are still facing problems with optimization of 2-DE techniques because the performance of optimization techniques in proteomics research using 2-DE has its own limitations. Therefore, the present study was established to generate a reproducible and optimized protocol to display the 2-DE protein map of human saliva. Our results showed the standard optimization of the 2-DE protein mapping was achieved at $\mathrm{pH} \mathrm{3-10} \mathrm{with} 60 \mu \mathrm{g}$ proteins loading. This protocol could be used by other scientists along with identification of differentially expressed proteins by mass spectrometry when 2-DE protein map of patients saliva are compared to that of normal healthy individuals. These differentially expressed proteins could be later used as specific and sensitive biomarkers for early diagnosis and prognosis of the disease in question. In conclusion, the procedure used in our study generated a highly reproducible and optimized reference 2-DE protein mapping of human saliva.
\end{abstract}

Keywords: Proteomics; 2-DE; Human saliva

Abbreviations: 2-DE: Two Dimensional Gel Electrophoresis; IEF: Isoelectric Focusing; SDS-PAGE: Sodium Dodecyl Sulfate Polyacrylamide Gel Electrophoresis; OSCC: Oral Squamous Cell Carcinoma

\section{Introduction}

Saliva is a unique and complex biofluid consisting of approximately $99 \%$ water with a mineral component consisting of electrolytes such as sodium, potassium, calcium, chloride, magnesium, bicarbonate and phosphates. The saliva component contains enzymes ( $\alpha$-amylase), secretory immunoglobulins (IgA, IgG and $\operatorname{IgM}$ ) and other antimicrobial factors, mucosal glycoproteins, traces of albumin and some polypeptides and oligopeptides [1,2]. These components interact with each other resulting in various functions such as taste, digestion $[3,4]$, protection, lubrication $[5,6]$, cleaning, buffering capacity [3] and maintaining integrity of the tooth structure [6].

Total or whole saliva is produced by three paired major salivary glands namely parotid, submandibular, and sublingual glands along with several hundred minor salivary glands spread throughout the oral cavity together with gingival and crevicular fluid [1,2]. Over the past decade, the use of saliva as an auxiliary diagnostic tool for biomarker detection has gained considerable acceptance as a non-invasive, inexpensive alternative to conventional serum method $[7,8]$.

The range of diseases which can be identified using salivary diagnostics are ever increasing [7-10], and salivary biomarkers have been used for detecting several diseases such as acute myocardial infarction [11,12], pancreatic cancer [13,14], oral squamous cell carcinoma (OSCC) $[15,16]$, breast cancer $[17,18]$, and periodontal diseases $[19,20]$. The detection of various biomarkers in saliva has also been reported to help with early diagnosis of autoimmune diseases such as rheumatoid arthritis and Sjögren's syndrome [21,22].

In proteomics, the most promising technique which can be used for detecting salivary biomarker with sufficient resolving power is twodimensional gel electrophoresis (2-DE) that provides a unique platform for the simultaneous separation of proteins in a complex mixture [23]. However, as a fact most of the new scientists in developing countries are still facing problems with optimization of 2-DE techniques because the performance of optimization techniques in proteomics research using 2-DE has its own limitations [23].

Therefore in this study, it was thought worthwhile to establish and generate a reproducible and optimized protocol to display the complete qualitative 2-DE protein map of the human saliva. This protocol could be used by other scientist along with identification of differentially expressed proteins by mass spectrometry when 2-DE protein map of

*Corresponding authors: Saeid Reza Doustjalali, Faculty of Medicine SEGiUniversity, Malaysia, Tel: +603-61451777; E-mail:saeidrezad@yahoo.com

Negar Shafiei Sabet, Faculty of Medicine, SEGiUniversity, Malaysia, Tel: +60361451777; E-mail:negar_4@yahoo.com

Received July 01, 2015; Accepted September 28, 2015; Published September 30, 2015

Citation: Doustjalali SR, Yaldrum A, Al-Jashamy K, Irfan M, Zin KT, et al. (2015) Protein Map Standardization of Human Saliva Using Two Dimensional Gel Electrophoresis (2-DE). J Mol Biomark Diagn 6: 249. doi:10.4172/21559929.1000249

Copyright: ( 2015 Doustjalali SR, et al. This is an open-access article distributed under the terms of the Creative Commons Attribution License, which permits unrestricted use, distribution, and reproduction in any medium, provided the original author and source are credited 
patients saliva are compared to that of normal healthy individuals. These differentially expressed proteins could be later used as specific and sensitive biomarkers for early diagnosis and prognosis of the disease in question.

\section{Materials and Methods}

\section{Protein extraction of human saliva}

The extraction of protein from human saliva was performed as shown in the flowchart (Figure 1). Finally all samples were stored at $-80^{\circ} \mathrm{C}$ and subjected to the similar 2-DE treatment. The research proposal was approved by the Ethics Committee of SEGi University.

\section{2-DE gel electrophoresis optimization}

The first-dimension Isoelectric Focusing (IEF) was performed by using PROTEAN IEF system (Bio-Rad Laboratories, USA). $60 \mu \mathrm{g}$ of protein sample was supplemented with $60 \mu \mathrm{l}$ sample buffer solution ( 9 $\mathrm{M}$ urea, $0.5 \% \mathrm{v} / \mathrm{v}$ Triton X-100, 2\% v/v IPG buffer $\mathrm{pH} 3-10$ and $60 \mathrm{mM}$ DDT) and left at room temperature $\left(20^{\circ} \mathrm{C}\right)$ for 30 minutes. The mixture was added with rehydration solution $(8 \mathrm{M}$ urea, $0.5 \% \mathrm{v} / \mathrm{v}$ Triton $\mathrm{X}-100$, $0.5 \%$ v/v IPG buffer pH 3-10, $12 \mathrm{mM}$ DDT and $0.002 \%$ of Orange G) to make final volume of $200 \mu \mathrm{l}$ for $11 \mathrm{~cm}$ IPG Strip gel, pH 3-10 (BioRad Laboratories, USA), respectively [24-27]. The IPG strips were then rehydrated with the sample mixture in the Immobiline Dry Strip Reswelling Tray. The reswelling tray and IPG strips were rehydrated at room temperature for 16 hours.

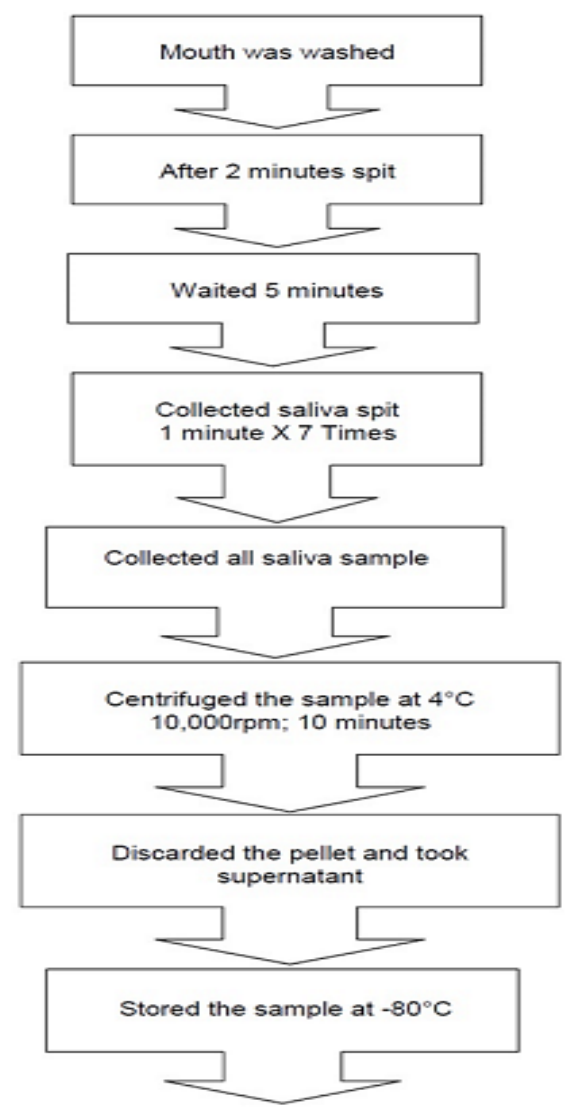

Figure 1: Flowchart of protein extraction of human saliva. The extraction of protein from human saliva was performed as shown in the flowchart. Finally all samples were stored at $-80^{\circ} \mathrm{C}$ and subjected to the similar 2-DE treatment.

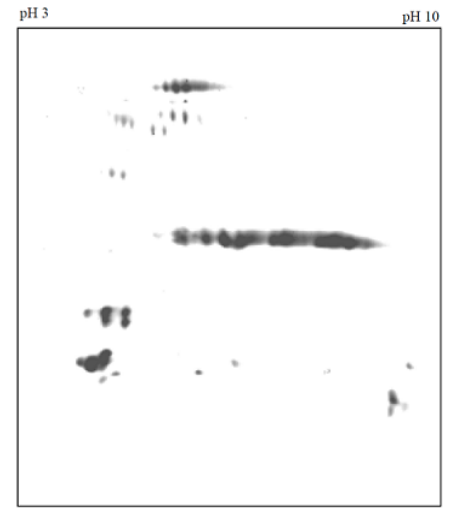

Figure 2: Typical 2-DE protein profiles of human saliva. The 2-DE analyses were optimized at $\mathrm{pH} 3-10$ with $60 \mu \mathrm{g}$ proteins loading.

Isoelectric focusing (IEF) was performed under the following conditions: $300 \mathrm{~V}$ for 30 minutes, $3500 \mathrm{~V}$ for remaining hours till reached $12000 \mathrm{~V} / \mathrm{hr}$. Upon completion of IEF the strips were equilibrated in equilibration buffer ( $6 \mathrm{M}$ urea, $1.5 \mathrm{M}$ Tris- $\mathrm{HCl}, \mathrm{pH} 8.8,30 \% \mathrm{v} / \mathrm{v}$ Glycerol, $2 \%$ SDS, $0.002 \%$ bromophenol blue, 0.06 M DTT) for 15 minutes, followed by the same buffer containing $240 \mathrm{mM}$ iodoacetamide instead of DTT for another 15 minutes. The second dimension separation was carried out at $16^{\circ} \mathrm{C}$ on $12.5 \%$ SDS slab gels using 2-DE system (Bio-Rad Laboratories, USA), with the IPG strips sealed on the top of the gels with $0.5 \%$ agarose. SDS-PAGE was run for $40 \mathrm{~mA} / \mathrm{gel}$ at $50 \mathrm{~V}$ for the first 30 minutes. The voltage was subsequently increased to $600 \mathrm{~V}$ until the bromophenol blue marker reached the bottom of the gel [24-27].

\section{Silver staining}

The 2-DE gels were developed by silver staining as previously described by Heukeshoven and Dernick [28].

\section{Image analysis}

Protein spots were analyzed and images of stained 2-DE gels were acquired with Platinum Image Master Scanner (Amersham Biosciences) and stored as TIF file. All samples were analyzed in triplicate.

\section{Results and Discussion}

Salivary biomarkers can be used for diagnosis of several diseases such as acute myocardial infarction, pancreatic cancer, oral squamous cell carcinoma (OSCC), breast cancer, periodontal diseases and autoimmune diseases such as rheumatoid arthritis and Sjögren's syndrome [7-22]. In proteomics, the most promising technique which can be used for detecting salivary biomarker with sufficient resolving power is 2-DE that provides a unique platform for the simultaneous separation of proteins in a complex mixture [23]. However, as a fact most of the new scientists in developing countries are still facing problems with optimization of 2-DE techniques because the performance of optimization techniques in proteomics research using 2-DE has its own limitations [23]. Therefore it was important to have an optimized system for developing 2-DE protein map to display the complete qualitative 2-DE protein map of the human saliva.

In our study consistency, optimization and reproducibility were achieved by standardizing the procedures for the extraction of protein from human saliva, the first and second dimension of electrophoresis, gel staining and image acquisition. Figure 2 shows the 2-DE protein maps of human saliva. The 2-DE analyses were optimized at $\mathrm{pH} 3-10$ with $60 \mu \mathrm{g}$ proteins loading. Under these conditions, proteins could 
Citation: Doustjalali SR, Yaldrum A, Al-Jashamy K, Irfan M, Zin KT, et al. (2015) Protein Map Standardization of Human Saliva Using Two Dimensional Gel Electrophoresis (2-DE). J Mol Biomark Diagn 6: 249. doi:10.4172/2155-9929.1000249

be visualized without much background noise and sacrificing gel resolution. Thus we have established a robust, reliable and optimized protocol for the 2-DE protein profile of human saliva.

This protocol could be used by other scientists along with identification of differentially expressed proteins by mass spectrometry when 2-DE protein map of patients saliva are compared to that of normal healthy individuals. These differentially expressed proteins could be later used as specific and sensitive biomarkers for early diagnosis and prognosis of the disease in question. In conclusion, the procedure used in our study generated a highly reproducible and optimized reference 2-DE protein mapping of human saliva.

\section{Competing Interests}

The authors declared they have no competing interests.

\section{Authors' contributions}

Conceived and designed the experiments: SRD. Performed the experiments: SRD NSS. Analyzed the data: SRD KAJ NSS. Wrote the paper: SRD KAJ NSS. Revised the paper: SRD AY KAJ MI KTZ NHL WML VA SYAK JN RM WAC HH AY RSYW VK CPWT NSFS HA ANAAR MM SDS NSS. All authors read and approved the final manuscript to be published.

\section{Acknowledgements}

This study was supported by Ministry of Higher Education (MOHE), Malaysia under the High Impact Research (HIR)-MOHE UM.C/625/1/HIR/MOHE/H-20001$00-E 000079$ and Fundamental Research Grant Scheme (FRGS) FP027-2010B.

\section{References}

1. Edgar WM (1992) Saliva: its secretion, composition and functions. Br Dent $J$ 172: 305-312.

2. Humphrey SP, Williamson RT (2001) A review of saliva: normal composition, flow, and function. J Prosthet Dent 85: 162-169.

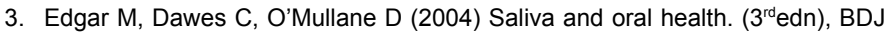
Books, London.

4. Ten Cate AR (1998) Oral histology: development, structure and function. (5 edn.) St. Louis: Mosby.

5. Stack KM, Papas AS (2001) Xerostomia: etiology and clinical management. Nutr Clin Care 4: 15-21.

6. Axelsson P (2000) Diagnosis and risk prediction of dental caries. v. 2. Illinois: Quintessence books.

7. Ilyin SE, Belkowski SM, Plata-Salamán CR (2004) Biomarker discovery and validation: technologies and integrative approaches. Trends Biotechnol 22 411-416.

8. Nunes LA, Mussavira S, Bindhu OS (2015) Clinical and diagnostic utility of saliva as a non-invasive diagnostic fluid:a systametic review Biochem Med (Zagreb) 25: 177-192.

9. Mandel ID (1993) Salivary diagnosis: more than a lick and a promise. J Am Dent Assoc 124: 85-87.
10. Malon RS, Sadir S, Balakrishnan M Córcoles EP (2014) Saliva-based biosensors: noninvasive monitoring tool for clinical diagnostics. Biomed Res Int.

11. Chatterton RT Jr, Vogelsong KM, Lu YC, Ellman AB, Hudgens GA (1996) Salivary alpha-amylase as a measure of endogenous adrenergic activity. Clin Physiol 16: 433-448.

12. Rahim MA, Rahim ZH, Ahmad WA, Hashim OH (2015) Can Saliva Proteins $\mathrm{Be}$ Used to Predict the Onset of Acute Myocardial Infarction among High-Risk Patients?. Int J Med Sci 12: 329-335.

13. Wong DT, Zhang L, Farrell J, Zhou H, Elashoff D, et al. (2009) Salivary biomarkers for pancreatic cancer detection. Gasteroenterology 138: 949-57e1-7.

14. Jiang J, Liu HL, Liu ZH, Tan SW, Wu B (2015) Identification of cystatin SN as a novel biomarker for pancreatic cancer. Tumour Biol 36: 3903-3910.

15. Li Y, St John MA, Zhou X, Kim Y, Sinha U, et al. (2004) Salivary transcriptome diagnostics for oral cancer detection. Clin Cancer Res 10: 8442-8450.

16. Mu AK, Chan YS, Kang SS, Azman SN, Zain RB (2014) Detection of hostspecific immunogenic proteins in the saliva of patients with oral squamous cel carcinoma. J. Immunoassay Immunochem 35(2): 183-193.

17. Tabak LA (2001) A revolution in biomedical assessment: the development of salivary diagnostic. J dent educ 65: 1335-1339.

18. Cheng F, Wang Z, Huang Y, Duan Y, Wang X (2015) Investigation of salivary free amino acid profile for early diagnosis of breast cancer with ultra-performance liquid chromatography-mass spectrometry. Clin Chim Acta 447: 23-31.

19. Haffajee AD, Socransky SS (1994) Microbial etiological agents of destructive periodontal diseases. Periodontol 2000 5: 78-111.

20. Hendek MK, Erdemir EO, Kisa U (2015) Evaluation of salivary procalcitonin levels in different periodontal diseases. J Periodontol 86: 820-826.

21. Mirrielees J, Crofford LJ, Lin Y, Kryscio RJ, Dawson DR 3rd, et al. (2010) Rheumatoid arthritis and salivary biomarkers of periodontal disease. $\mathrm{J}$ Clin Periodontol 37: 1068-1074

22. Delaleu N, Mydel P, Kwee I, Brun JG, Jonsson MV (2015) High fidelity between saliva proteomics and the biologic state of salivary glands defines biomarke signatures for primary Sjögren's syndrome. Arthritis Rheumatol 67: 1084-1095.

23. Doustjalali SR, Munira B, Karim Al-Jashamy, Nyan HL, Samiah YAK, et al. (2014) Two dimensional gel electrophoresis: An overview of proteomic technique in cancer research. Journal of Proteomics and Bioinformatics 7: 3 077-081.

24. Doustjalali SR, Yusof R, Yip CH, Looi M, Pillay B, et al. (2004) Aberrant expression of acute-phase reactant proteins in sera and breast lesions of patients with malignant and benign breast tumors. Electrophoresis 14: 2392-2401.

25. Doustjalali SR, Yusof R, Govindasamy GK, Bustam AZ, Pillay B, et al. (2006) Patients with nasopharyngeal carcinoma demonstrate enhanced serum and tissue ceruloplasmin expression. The Journal of Medical Investigation 53: 20-28.

26. Ng MH, Doustjalali SR, Pathak R, Sabet NS, Khor SF, et al. (2013) Two dimensional protein map standardization of human bone marrow stromal cells. $\mathrm{J}$ Proteomics and Bioinformatics 6: 85-88.

27. Doustjalali SR, Munira B, Karim Al-Jashamy, Mohammed I, Magdi ES, et al (2015) Differential expression of serum ceruloplasmin and a2-HS glycoprotein among nasopharyngeal carcinoma patients. Journal of Molecular Biomarkers \& Diagnosis. http://dx.doi.org/10.4172/2155-9929.S2-0011.

28. Heukeshoven J, Dernick R (1988) Improved silver staining procedure for fast staining in Phast System development unit. I. Staining of sodium dodecyl sulphate gels. Electrophoresis 9: 28-32. 